\title{
The Fisher Effect in an Emerging Economy: The Case of India
}

\author{
Milind Sathye (Corresponding author) \\ School of Business, University of Canberra \\ Canberra, Australia \\ Tel: 612-6201-5489Ｅ-mail: Milind.Sathye@canberra.edu.au
}

\author{
Dharmendra Sharma \\ School of Information Sciences and Engineering, University of Canberra \\ Canberra, Australia \\ E-mail: Dharmendra.Sharma@canberra.edu.au
}

\author{
Shuangzhe Liu \\ School of Information Sciences and Engineering, University of Canberra \\ Canberra, Australia \\ Shuangzhe.Liu@canberra.edu.au
}

\begin{abstract}
The objective of this study is to test the relationship between short-term nominal interest rate and inflation in the context of the Indian financial market. To achieve this objective we perform Augmented Dickey-Fuller unit root test to check for stationarity and thereafter we test for co-integration using the Engle-Granger method and further corroborate the findings of this test with the Johansen-Juselius method. Lastly, we perform the Granger causality test. Monthly data of inflation and nominal short term interest rates for the period from April 1996 to August 2004 were used. We find that expected inflation and nominal short-term interest rates are co-integrated in the Indian context. Thus, the present study doesn't reject the Fisher effect in the Indian financial market. This test shows that expected inflation is Granger caused by nominal short term interest rates. These findings are important in the context of financial market policies in emerging economies like India.
\end{abstract}

Keywords: Co-integration, Fisher effect, Indian economy, Engle-Granger

\section{Introduction}

The objective of this study is to test the relationship between nominal short-term interest rate (NSTIR) and inflation in the context of the Indian financial market. To achieve this objective we perform Augmented Dickey-Fuller (ADF) and the Phillips-Perron (PP) test on these two time series to diagnose their stationarity. Where a unit root is found the series is first differenced. Thereafter we test for co-integration using the Engle-Granger method and further corroborate the findings of this test with the Johansen-Juselius method. We find that inflation and nominal short-term interest rates are co-integrated in the Indian context. Thus, the present study doesn't reject the Fisher effect in the Indian financial market. Lastly, we perform the Granger causality test. This test shows that inflation is Granger caused by NSTIR.

The motivation for the study comes from two perspectives. Firstly, India is an emerging economy and findings of the study would help policy makers to take suitable policy initiatives in that economy. Understanding the relationship between interest rates and other variables such as inflation is central to the study of financial markets and for policy making in these markets. Secondly, all empirical studies concerning the Fisher hypothesis have primarily focused on US and European economies. No published study to our knowledge exists that has examined the relationship in the context of an emerging economy like India. The paper is organized as follows: the next section is a snapshot of the Indian economy, section 3 reviews literature on the Fisher hypothesis, section 4 is about data and methods, section 5 presents the findings of the study and section 6 concludes.

\section{A snapshot of the Indian economy}

The Indian economy achieved a growth rate of 8.2 per cent in the financial year 2004 and is considered to be the fastest growing free-market democracy in the world. It is one of the world's largest food producers, which produces 600 million tonnes of food grains every year holding a buffer stock of nearly 50 million tonnes of food grains (wheat and rice) in 2003-2004. It is also the second largest exporter of rice and the fifth largest exporter of wheat in the world; its agricultural exports account for nearly 14.2 percent of its total exports. The Indian services sector is growing 
consistently at a rate of 7 percent per annum and accounted for almost half of the country's GDP in the 2004 financial year. India's foreign exchange reserves stood at a record high of \$120.78 billion in July 2004.

The financial markets and financial institutions in India are quite well developed. The financial institutions in India comprise deposit taking institutions like commercial banks and cooperative banks, long-term financial institutions like the Industrial Development Bank of India (IDBI), savings institutions like the Unit Trust of India (UTI), life and general insurance companies, superannuation funds and non-bank financing companies. Commercial banks dominate the financial sector in India. The assets of Indian commercial banks formed $64 \%$ of the total assets of the financial institutions in India. As at the end of June 2003, there were 295 commercial banks comprising 27 public sector banks, 32 private sector banks, 40 foreign banks and 196 regional rural banks. The cooperative banking sector consisted of 52 urban cooperative banks and 16 state cooperative banks (RBI-RTPB, 2003). The following financial indicators of Indian commercial banks may be of interest.

Even prior to India's political independence in August 1947, she had a well-developed stock market. India's major financial markets could be grouped under five broad categories: the money market, foreign exchange market, debt market (government securities market), equity market and the derivatives market.

\section{Literature on the Fisher effect}

The Fisher's hypothesis is regarded as one of the most important hypotheses in macroeconomics. Fisher (1930) postulated that the nominal interest rate consists of an expected 'real' rate plus an expected inflation rate. He claimed a one-to-one relationship between inflation and interest rates. Real interest rates he claimed were unrelated to the expected rate of inflation and were determined entirely by the real factors in an economy, such as the productivity of capital and investor time preference.

It has implications in the context of real purchasing power of money, asset valuation and capital market efficiency, and is important for understanding the movements in nominal interest rates. The savings and investment decisions in any economy are guided by the real interest rates. Understanding the relationship between interest rates and other variables such as inflation is, therefore, central to the study of financial markets.

Many studies in the United States and Europe have tested the Fisher hypothesis over the years. These studies have yielded mixed results. The studies of Fama (1975), Atkins (1989), Mishkin (1992) and Crowder and Hoffman (1996) found support for the Fisher hypothesis but studies such as those by Mishkin $(1981,1984)$, Barthold and Dougan (1996) and Rose (1988) have shown contradictory results. Some other studies like those of MacDonald and Murphy (1989), Wallace and Warner (1993) and Engsted (1996) found that findings varied with time periods and across countries. As already noted these studies were in the context of US and Europe. Almost all the studies have examined the relationship between NSTIR and inflation and no strong evidence of the existence of the Fisher effect was noticed in these studies. In the context of emerging economies like India, Thomas Paul (1984) examined the Fisher effect. It has been more than two decades now and important changes have taken place in the Indian economy. When the Thomas Paul study was conducted, the economy was very much repressed. However, since 1991, the government has followed a policy of market liberalisation. The economic situation in India has changed dramatically. Many regulations have been removed and the economy is on a high growth rate path. Consequently, there is a need to examine the Fisher effect in changed economic conditions. However, we have not come across any study that has done this in recent years, that is, after the Thomas Paul Study. This study thus bridges a major gap in the literature by examining the Fisher hypothesis in an emerging economy and could help guide further research in this area.

\section{Data and methods}

The data required for the study was collected from the Handbook on Indian Statistics published by the Reserve Bank of India which is available at their website. Monthly consumer price index values and monthly yield rates on Treasury bills of 90 days were used. The period covered was from April 1996 to August 2004 (101 months) as the data of these years is available at the Reserve Bank of India website. Monthly inflation rates were calculated as the first difference of the natural logarithm of the consumer price index. Almost all the previous studies on the Fisher hypothesis have examined the relationship between NSTIR and inflation. The question that this study addresses is similar to that of Engsted (1996): whether or not nominal short-term interest rates reflect expected inflation. The procedure that we follow to investigate this phenomenon follows. Firstly, we examine whether the two series under investigation are stationary. We do this by applying the ADF unit root test. Secondly, we examine if the first difference of these series is stationary and in that case perform the Engle-Granger test of co-integration. Thereafter we investigate the relationship between NSTIR and inflation by ordinary least squares regression. Such regressions include 'the possibility of obtaining spurious or dubious results in the sense that superficially the results look good but on further probing they look suspect' (Gujarati, 1995, p. 724). This situation has also been described by Granger and Newbold (1974) and by Phillips (1986). Thirdly, we perform the Johansen-Juselius (1990) procedure to further confirm results of the above 
Engle-Granger test of co-integration. Finally, we run the Engle-Granger Causality test together with the Error Correction Model to examine whether the two series display any causal relationship. The present study is different from the Engsted (1996) study as it uses monthly data and represents a longer time series than does Engsted's study, which used quarterly data.

\section{Empirical Results}

\subsection{Unit root test}

Table 2 reports the results of the ADF unit root test. The results reveal that the null hypothesis of unit root can't be rejected at the levels for inflation rate series and short-term interest rate series. However, the results of ADF for both the series at first difference show that the series are now stationary. Thus NSTIR and inflation rate are both I (1) processes.

\subsection{Co-integration Tests: The Engle-Granger Method}

Given that both the processes are of the same order of integration, one can now proceed to test for co-integration. We estimate the long-term relationship in linear form by the ordinary least squares method and present the results in Table 3 below.

The model is not a good fit when the inflation series is regressed on NSTIR in level. The values of $\mathrm{R}^{2}$ and adjusted $\mathrm{R}^{2}$ are insignificant. The coefficients are not significant either. We conclude that the standard regression interpretation of the coefficients is not valid. This leads us to the Engle-Granger test of the residuals from this regression. The ADF and the PP unit root test were applied to the residuals. The results from these tests are presented in Table 4 below and suggest that the residuals are strongly stationary and the series are co-integrated.

\subsection{Co-integration Tests: The Johansen-Juselius Method}

For bi-variate time series, the Engle-Granger co-integration method described above should be adequate. However, to further corroborate the above results we apply a more general technique developed by Johansen $(1988,1991)$ and by Johansen and Juselius (1990). They proposed a maximum likelihood estimation procedure, which allows researchers to estimate simultaneously the system involving two or more variables.

To test the hypothesis of no co-integrating relations $(r=0)$ against the general alternative of $r>0$ the trace test statistic has a calculated value of 30.044 . The $10 \%$ critical value is 28.4 and so the null is rejected. To test the null that $r=0$ against the alternative that $r=1$, the maximum eigenvalue test statistic is reported as 22.506; again this is more than the $10 \%$ critical value of 19.0. The general conclusion is that there is evidence to support the co-integrating relation in the data series. These findings are similar to that of the Thomas Paul (1984) study.

\subsection{Granger causality}

The fact that the two series are co-integrated doesn't mean that one causes the other. To test whether NSTIR causes expected inflation needs to be checked. We deploy the test of Granger causality to check this. We perform two tests. In test 1 our null hypothesis is that NSTIR doesn't Granger cause expected inflation. For test 2 our null hypothesis is that expected inflation doesn't Granger cause NSTIR. We include the relevant error correction term. The results are as shown in Table 5.

In summary, Granger causality test results show that short-term nominal interest rates help in predicting future inflation.

\section{Conclusion}

This study examined the relevance of the Fisher effect in the context of an emerging economy like India. Data required for the study was available from the Handbook on Statistics of the Reserve Bank of India. The period covered was from April 1996 to August 2004 (100 months observations). The ADF unit root test showed that the series of expected inflation and nominal short-term interest rates are not stationary at levels but are both I (1) processes. Thereafter the co-integration test (Engle-Granger method) was used which showed that the series are co-integrated. This finding was confirmed by the Johansen-Juselius method. Finally we used the Granger causality test with error correction model to determine the direction of the relationship. The results showed that short-term nominal interest rates do help in predicting future inflation in the Indian context.

\section{References}

Atkins, F. J. (1989). Co-integration, error correction and the Fisher effect, Applied Economics, vol. 21, 1611-1620

Barthold, T. and Dougan, W. (1986). The Fisher hypothesis under different monetary regimes, Review of Economics and Statistics, November, pp. 674-679

Crowder, W. and Hoffman, D. (1996). The long run relationship between nominal interest rates and inflation: The Fisher equation revisited, Journal of Money, Credit and Banking, vol. 28, 102-118 
Engsted, T. (1996). Does the long-term interest rate predict future inflation? A multi-country analysis, Review of Economics and Statistics, 42-54

Fama, E. F. (1975). Short-term interest rate and inflation, American Economic Review, June, 269-282

Fisher, I. (1930). The theory of interest, New York: Macmillan.

Granger, C. W. and Newbold, P. (1974). Spurious regression in econometrics, Journal of Econometrics, vol. 2, 11-20

Gujarati, D. N. (1995) Basic econometrics, New York: McGraw-Hill.

Indian Banks' Association, 2003. Performance highlights of banks: public sector banks, Indian Banks' Association, Mumbai.

Johansen, S. (1988). Statistical analysis of co-integrating vectors, Journal of Economic Dynamics and Control, vol. 12, June-Sept., 231-254

Johansen, S. (1991). Estimation and hypothesis testing of co-integration vectors in Gaussian vector autoregressive models, Econometrica, vol. 59, Nov. 1551-1580

Johansen, S., and Juselius, K. (1990). Maximum likelihood estimation and interference on co-integration with applications to demand for money, Oxford Bulletin of Economics and Statistics, vol. 52, May, 169-210

MacDonald, R. and Murphy, P. D. (1989). Testing for the long-run relationship between nominal interest rates and inflation using cointegration technique, Applied Economics, vol 21, 439-447

Mishkin, F. S. (1984) The real interest rate: a multi-country empirical study, Canadian Journal of Economics, vol. 17, 283-311

Mishkin, F. S. (1992). Is the Fisher effect for real, Journal of Monetary Economics, vol. 30, 195-215

Phillips, P. C. B. (1986). Understanding spurious regression in econometrics, Journal of Econometrics, vol. 33, 311-340

Reserve Bank of India (RBI). 2003. Report on trend and progress of banking in India (RTPB), Reserve Bank of India, Mumbai.

Reserve Bank of India (RBI). 2004. Handbook on statistics relating to Indian economy, Reserve Bank of India, Mumbai.

Rose, A. (1988). Is the real interest rate stable? Journal of Finance, vol. 43, 1095-1112

Thomas Paul, M. (1984). Interest rates and the fisher effect in India: An empirical study, Economics Letters, 1984, vol. 14 , issue $1,17-22$

Wallace, M. and Warner, J. (1993). The Fisher effect and the term structure of interest rates: tests of cointegration, The Review of Economics and Statistics, 320-324

Table 1. Financial indicators of banks in India

\begin{tabular}{|l|l|}
\hline & As of June 2003 \\
\hline Number of Commercial banks & 295 \\
\hline Number of branches of State Cooperative Banks & 66,514 \\
\hline Total deposits Rs trillion & $12.43^{@}$ \\
\hline Total loans and advances Rs trillion & $7.14^{\varrho}$ \\
\hline Total Assets (Rs trillion) & 15.35 \\
\hline Net Profit after provisions (Rs trillion) & 0.17 \\
\hline Provision for NPAs (Non Performing Assets) & 0.22 \\
\hline Total staff (Public Sector Banks only) & 755,437 \\
\hline Return on Assets (Ratio of operating profit to total assets) & range 0.024 \\
\hline Population per branch & 16,000 \\
\hline
\end{tabular}

(a) As of September 2003. (Source: Reserve Bank of India (RBI). 2003. Report on Trend and Progress of Banking in 
India (RTPB), Reserve Bank of India, Mumbai. Indian Banks' Association, 2003. Performance Highlights of Banks: Public Sector Banks, Indian Banks’ Association, Mumbai)

Table 2. Results of ADF test

\begin{tabular}{|c|c|c|c|c|}
\hline & \multicolumn{2}{|c|}{ Level } & \multicolumn{2}{c|}{$1^{\text {st }}$ difference } \\
\hline & t-statistics & Prob & t-statistics & Prob \\
\hline NSTIR & -3.089 & 0.1154 & -12.99 & 0.0001 \\
\hline CPI (Inflation rate) & -2.34 & 0.407 & -8.64 & 0.0000 \\
\hline
\end{tabular}

Table 3. Results of co-integrating equation

\begin{tabular}{|l|l|}
\hline Variables & Co-integrating equation \\
\hline NSTIR & $0.578 \quad(1.102)$ \\
\hline Constant & $0.437 \quad(0.108)$ \\
\hline $\mathrm{R}^{2}$ & 0.0125 \\
\hline Adjusted $\mathrm{R}^{2}$ & 0.0022 \\
\hline SEE & 110.24 \\
\hline
\end{tabular}

Table 4. Results of ADF and PP Tests on the Residuals from Long-run Regression

\begin{tabular}{|l|l|l|l|l|}
\hline \multicolumn{2}{|l|}{ ADF test } & PP test \\
\hline Variable & Level & Critical value & Level & Critical value \\
\hline Residuals & $-4.1074^{*}$ & -3.13 & $-8.7394^{*}$ & -3.13 \\
\hline
\end{tabular}

* Significant at $10 \%$ level 
Table 5. Granger causality test with error correction model: Vector Error Correction estimates

\begin{tabular}{|l|l|l|}
\hline Co-integrating Eq: & CointEq1 & \\
\hline CPI (-1) & 1.000000 & \\
\hline TBILLYIELD (-1) & 77.68343 & \\
\hline & $(25.9460)$ & \\
\hline & {$[2.99404]$} & \\
\hline C & -1029.163 & \\
\hline Error Correction: & $\mathrm{D}(\mathrm{CPI})$ & $\mathrm{D}$ (TBILLYIELD) \\
\hline CointEq1 & -0.003627 & -0.002828 \\
\hline & $(0.00448)$ & $(0.00107)$ \\
\hline & {$[-0.80940]$} & {$[-2.65251]$} \\
\hline R ${ }^{2}$ & 0.016135 & 0.193677 \\
\hline Adj. ${ }^{2}$ & -0.045356 & 0.143282 \\
\hline Sum sq. resides & 1981.092 & 112.1245 \\
\hline S.E. equation & 4.976309 & 1.183873 \\
\hline F-statistic & 0.262398 & 3.843165 \\
\hline Log likelihood & -256.9221 & -133.4350 \\
\hline Akaike AIC & 6.114468 & 3.242675 \\
\hline Schwarz SC & 6.285701 & 3.413908 \\
\hline Mean dependent & 1.930233 & -0.083852 \\
\hline S.D. dependent & 4.867154 & 1.279046 \\
\hline Determinant resid covariance (dof adj.) & 34.60905 \\
\hline Determinant resid covariance & & -39.800354 \\
\hline Log likelihood & & -390.2348 \\
\hline Akaike information criterion & & \\
\hline Schwarz criterion & & \\
\hline & & \\
\hline & & \\
\hline & & \\
\hline
\end{tabular}

